\title{
A kínai-amerikai kereskedelmi szembenállás és ennek hatása a magyar nemzetbiztonságra ${ }^{2}$
}

\author{
The Chinese-US Trade Confrontation and Its Impact on Hungarian \\ National Security
}

A kínai-amerikai kereskedelmi háború mind élesebb keretek között zajlik. Hatása nemcsak a két állam kapcsolataiban mutatkozik meg, hanem gyakorlatilag mind látványosabban jelentkezik az államközi viszonyokban is. A kiélezett gazdaságpolitikai helyzet olyan új szituációt teremt a nemzetközi viszonyrendszerben, amelyre a globális közösség nincs felkészülve, hiszen korábban példa nélküli hatással járó események sora következhet be.

A magyar nemzetbiztonság vonatkozásában számos új kihivás is megjelenne a kínai-amerikai kereskedelmi konfliktus kiszélesedésével párhuzamban. Az új helyzet keretei nagyjából meghatározhatók, azok rögzítése lényeges is a nemzetbiztonság szavatolása érdekében. Az esetleges új biztonsági környezet jelentette kihivásokra azonban érdemes időben felkészülni. Az esetlegesen kialakuló új, kedvezőtlen nemzetközi viszonyrendszer a felkészületlenség hiányában ugyanis jelentős nemzetgazdasági sérelmekkel járhat.

Kulcsszavak: kereskedelmi háború, Magyarország, Kína, USA, gazdaságbiztonság, globális biztonság

The Chinese-American trade war is intensifying. Its impact can be felt not only in the two states' relations but - more and more spectacularly - in the interstate relations too. The tense economic policy situation generates new conditions in the international

Kasznár Attila adjunktus, Miskolci Egyetem Bölcsészettudományi Kar Alkalmazott Társadalomtudományok Intézet, ORCID: 0000-0002-5498-0855

2 A kutatást az EFOP-3.6.2-16-2017-00007 azonosító számú, „Az intelligens, fenntartható és inkluziv társadalom fejlesztésének aspektusai: társadalmi, technológiai, innovációs hálózatok a foglalkoztatásban és a digitális gazdaságban" című projekt támogatta. A projekt az Európai Unió támogatásával, az Európai Szociális Alap és Magyarország költségvetése társfinanszírozásában valósul meg. 
relations that the global community is not prepared for, since a lot of unprecedented event may occur. Referring to the Hungarian national security, several new challenges could emerge paralelly with the widening Chinese-American commercial conflict.

The frames of the new situation can be and have to be determined in order to ensure national security. It is worth being on guard with regard to the challenges of the new security environment. The new, unfavourable international relations that might take shape could cause significant problems in the national economy due to unpreparedness.

Keywords: trade war, Hungary, China, USA, economy security, global security

\section{Bevezetés}

2018 nyarán vette kezdetét a kínai-amerikai kereskedelmi háború, ${ }^{3}$ amely mára a világgazdaság egyik legmeghatározóbb, legbizonytalanabb kimenetelú és rendkívüli biztonsági kockázatokkal fenyegető eseménysorává vált. A Kínai Népköztársaság és az Amerikai Egyesült Államok között végbemenő gazdasági konfliktushalmaz olyan új viszonyrendszer-kiépülés létrejöttének lehetőségével fenyeget, amelynek minimális számú haszonélvezője volna.

A 21. század elején végbemenő világméretű, a Kínai Népköztársaság felemelkedését eredményező gazdasági és politikai folyamatok természetesen magukban hordozták, hogy előbb-utóbb a két globális nagyhatalom szembekerül egymással. „Az új évszázadban két, bizonyos szempontból egymás ellen ható tendencia jelent meg. A kínai-amerikai kapcsolatok számos kérdésben többnyire az együttműködés irányába haladtak. Idővel azonban a történelemben és a geopolitikai irányultságban gyökerező különbségek is kezdtek nyilvánvalóvá válni." ${ }^{\prime 4}$

A nézőpontok azonban különbözők, így ami az egyik oldalon pozitívumként jelentkezik, az a másik félnél pontosan ellenkező előjelű folyamatokat indíthat be, amint az jelen esetben is tapasztalható. „Kína számos gazdasági mutató tekintetében túlszárnyalta az USA-t, s amint a jelenlegi kereskedelmi háború támogatottsága is mutatja, az amerikai politikában pártoktól függetlenül aggodalom kísérte a kínai felemelkedés folyamatát."5 Az aggodalom érzését pedig felerősítette, hogy az amerikaiak Kínával szembeni gazdasági térvesztése főként bizonyos csúcstechnológiát megvalósító iparterületeken valósult meg, ez pedig egyértelmúen vezetett a két állam közti összeütközéshez, a kereskedelmi háborúhoz.

A globális gazdasági és kereskedelmi hálózatok múködése olyan komplex hálózati modellt képez, amelyben bármely szereplő cselekedete bármely egyéb szereplő életét befolyásolja. Egy olyan hálózati elven múködő rendszerben, mint a jelenlegi globális gazdasági-politikai képződmény, a legkisebb alkotót érő negatív hatás a többi résztvevőre is jelentős következményekkel jár. Az általános hatás sokkal jelentősebb 
abban az esetben, ha valamely meghatározó állam esetében jelentkezik a negatívum, amely akár dominóelv szerint végigsöpörhet az összes szereplőn.

A helyzet komolyságát jelzi, hogy a konfliktus kapcsán egyértelmú, hogy nem egyszerü kereskedelmi vagy gazdasági vészhelyzet léphet életbe a globális államközösség országaiban, hanem a gyakorlatban nemzetbiztonsági szintű probléma keletkezhet.

Jelen tanulmánynak nem célja, hogy a kínai-amerikai kereskedelmi háború komplex hátterét és hatásait bemutassa. Ehelyett a középpontba a konfliktus hátterének és forrásának egy sajátos aspektusú megközelítése kerül, miközben kiemelt figyelem irányul a két nagyhatalom elmérgesedett szembenállásából a magyar nemzetbiztonságot veszélyeztető esetleges fenyegetésekre.

\section{A kínai globális térnyerés sajátos háttere}

1987-ben, a kínai reformok atyja, Teng Hsziao-ping úgy vélekedett, hogy országának hosszú távú sikere a ritkaföldfémek kitermelésének és kereskedelmének kizárólagos felügyeletében rejlik. A 20. század egyik legkiemelkedőbb politikusa 1986-ban hirdette meg azon programját, amelyben előirányozta, hogy középtávon Kínának kell a ritkaföldfémek vezető exportőrévé válnia. Mind kevesebb kétség férhet hozzá, hogy az utóbbi időben egyértelművé válik annak a ténye: a Teng Hsziao-ping útmutatásainak nyomán elinduló és az azt követő Kínai Népköztársaság a ritkaföldfémek gyakorlatilag egyedüli exportőrévé válik.

Már a 2010-es évek elején az elképzelés valóra vált, és Kína az említett anyagok világkereskedelmének 97\%-át mondhatta magáénak. ${ }^{6}$ Ennek eredményeként pedig tulajdonképpen teljes mértékben a felügyelete alá vonta úgy az elektronikai termékek, mint a félvezetők, illetve a különféle hadiipari felszerelések gyártásában kulcsfontosságú alapanyagok globális kereskedelmét.

Joggal adódik a kérdés, hogy mi vezette Teng Hsziao-pinget arra, hogy a ritkaföldfémekben lássa országa fejlődésének zálogát, miért is tekintett ezekre az ásványi anyagokra úgy, mint a „kőolajkincsre,” amely Kínának adatott? Pontosan milyen célra is használhatók, és miért ennyire fontosak ezek az ásványi anyagok? Néhány igazán eklatáns példa a felhasználási területekre:

- chipek,

- merevlemezek,

- müholdak,

- radarkészülékek,

- katonai kommunikációs eszközök,

- hadászati dróntechnológia,

- mobil kommunikációs eszközök.

$6 \quad$ Ezen a ponton érdemes lehet megjegyezni, hogy számos ország rendelkezik, több esetben jelentős ritkaföldfém-tartalékkal, azonban a korábbi évtizedekben azok kitermelését leállították, mivel Kína olcsóbb forrásnak bizonyul, mint a saját kitermelés. További kérdés ugyanakkor, hogy a bányászati tevékenységet milyen gyorsasággal képesek újraindítani, annak költségeit tudják-e viselni, illetve vállalják-e a környezetszennyező eljárások alkalmazásából eredő társadalmi konfliktusokat. 
Teng pontosan tudta mire kíván építeni. „Tovább kell haladnunk az úton, a kínai típusú szocializmus felé. A kapitalizmust több száz éve építik. Milyen hosszú ideje építjük mi a szocializmust? Ráadásul elvesztegettünk húsz évet. Ha a Népköztársaság megalapításától számítva száz éven belül egy viszonylagosan fejlett országgá tudjuk tenni Kínát, az kiugró teljesítmény lesz."7 Kiemelkedő politikai zsenije és kimagasló stratégiai képességei hozzásegítették, hogy tökéletesen mérje fel az információs technológiában rejlő lehetőségeket, és azt, hogy tudatos, időt engedő, lassú lépésekre alapozó építkezéssel lehet Kínát ismét nagyhatalommá tenni. Kína pedig Teng Hsziao-ping útmutatása szerint, szépen csendben kezdett bele abba a több lábon álló, tudatos építkezésbe, amelynek eredményeként a modern információs technológiák gyártása során elengedhetetlen nyersanyagok lényegében kizárólagos kitermelőjévé vált.

A tengi tudatos építkezést mi sem jelzi jobban, minthogy mindezzel párhuzamosan a modern információtechnológiai eszközök jelentős része kapcsán a pekingi vezetésnek sikerült elérnie, hogy azokat Kínában gyártsák. Ennek eredményeként az ázsiai ország olyan globális függőséget alakított ki, amely szinte kihagyhatatlan szereplővé tette Kínát az információs társadalmak építése során. A kutatás-fejlesztés területén elért eredményeket jól mutatja, hogy az információtechnológia terén jelenleg csúcstechnológiát képező 5G-hálózatok fejlesztésében és kiépítésében a Kínai Népköztársaság jár az élen. Csakhogy az 5G-hálózatok építése, fejlesztése és felügyelete révén, az ezt megvalósító állam stratégiai gazdasági, információáramlási és információszerző előnyre tesz szert gyakorlatilag az összes többi globális szereplővel szemben, amely tény beláthatatlan politikai és társadalmi következményekkel jár a lemaradó államok esetében. Ennek eredményeként pedig „az USA, mint regnáló nagyhatalom fenyegetve érzi magát a gazdasági, politikai és katonai téren is rohamosan erősödő Kínai Népköztársasággal szemben, amit a Szovjetunió széthullása óta a legnagyobb kihívásnak tekint". ${ }^{\circ}$

Az Amerikai Egyesült Államok nemzetbiztonsági szakemberei felismerték a fentebb leírtakat, és ennek nyomán Washington elkeseredett harcot kezdett annak érdekében, hogy az 5G-fejlesztések globális infrastrukturális rendszerét ne a kínai beruházók építhessék ki. A szakértők szerint ugyanis, ha kínai vállalatok felügyelnék az 5G-rendszereket, akkor Washingtonnak és szövetségeseinek - így Magyarországnak is - jelentősen sérülnének nemzetbiztonsági érdekei. ${ }^{9}$ Ugyanakkor ezzel párhuzamosan az amerikai nemzetbiztonsági rendszer számos sebből vérzik, amelyek közül csak az egyik, hogy egyet nem értés miatt kénytelen volt lemondani Donald Trump nemzetbiztonsági tanácsadója, John Bolton. ${ }^{10} \mathrm{Ez}$ a tény pedig további indoklását adja a Kínával szembeni amerikai fellépésnek, amely tulajdonképpen egy kényszerü védekezési stratégia részeként is értelmezhető.

TENG 1992, 370.

MATURA 2019.

A szakértők leginkább attól tartanak, hogy mivel az adatforgalom Kína által felügyelt eszközökön zajlana, így gyakorlatilag, többek között az egyes államok nemzetgazdaságával, védelempolitikájával, illetve minden egyéb lényeges információjával, sőt az állampolgárokkal kapcsolatos személyes adatok is az ázsiai hatalom birtokába kerülhetnek.

10 Mandiner 2019. 
Nem véletlenül, hiszen már a laikusoknak is egyértelmű a legmodernebb információtechnológiai rendszerek terén a kínai fölény, amelyet elsősorban a Huawei testesít meg. Ennek eredménye az a globális szankcióhadjárat, amelyet az amerikai-kínai kereskedelmi háború keretében Washington hirdetett a kínai óriás ellen, és amelyhez több, az amerikai szövetségi rendszerhez tartozó állam - Japán, Tajvan, Ausztrália és Új-Zéland - csatlakozott. Mint azonban azt már fentebb is kifejtettem, a Huawei ellen bevezetett szankciók ténye leginkább annak a bizonyítékaként értelmezhető, hogy Kína bejelentkezett a globális nagyhatalmi pozícióra, amelynek ténye félelemmel tölti el a washingtoni döntéshozókat, hiszen Peking valóban rendelkezik azokkal a képességekkel, amelyek alkalmassá teszik erre, elsősorban a ritkaföldfémkészlettel, valamint annak felhasználásához való technológiával és szakértelemmel. Vagyis tulajdonképpen a ritkaföldfémkincs birtoklása, párosulva az 5G-technológia terén elért kínai fölénnyel az, amely a kínai-amerikai kereskedelmi háború igazi oka, hiszen ez az, amelyre egyik vagy másik fél technikai fölénye építhető.

Jelenleg megállapítható, hogy az 5G-hálózatok kapcsán kialakult konfliktus folyamatosan mélyül, és mindkét országban fokozódnak a kereskedelmi konfliktus miatti feszültségek. ${ }^{11}$ Az Amerikai Egyesült Államok és egyes szövetségesei, nemzetbiztonsági veszélyre hivatkozva, egymás után jelentik be, hogy kitiltják területükről a szakterületen világvezetőnek tekinthető kínai nagyvállalatokat. A kiterjedt kereskedelmi háború, amelynek kulcsütközete éppen az 5G-technológia néhol már-már a hidegháborús szembenállás jeleit mutatja. Eközben a fél világ döbbenettel áll a kialakult helyzet előtt és rémülten kérdezi: hogyan lehet, hogy a kínaiak a semmiből, egyszer csak kulcspozícióra tettek szert a legmodernebb infokommunikációs rendszerek kiépítésében? A valóság azonban egész más, Kína egy hosszú, és rendkívül tudatos építkezés eredményeként vált az információs technológia szuperhatalmává, amely építkezés megindítása Teng Hsziao-pinghez volt köthető. Teng Hsziao-ping zsenijét a kortársai is felismerték, azonban mára bebizonyosodott, hogy személyében a történelem egyik legnagyobb stratégáját tisztelhetjük. Teng ritkaföldfémekkel kapcsolatos felismerése igazi nagy ugrást jelentett Kínának, amelynek eredményeként a több ezer éves állam visszanyerte régi dicsőségét.

Ameddig Peking igyekezett megszerezni a technikai fölényt biztosító globális ritkaföldfémkészlet felügyeletét, addig a liberális kereskedelmi politikában és a technológiai, kulturális fölényében vakon hívő Amerikai Egyesült Államok mindinkább visszaszorította a ritkaföldfémek kitermelését. Sorra zárták be az amerikai bányákat, elsősorban környezetvédelmi okokra hivatkozva. Így az elmúlt évtizedek során a korszerű hadi- és információtechnológiához nélkülözhetetlen alapanyagok terén Washington importfüggővé vált, miközben a modern információtechnológia terén visszaesett a kutatás-fejlesztés volumene. A korábban az információtechnológia úttörő államaként számon tartott amerikaiak a legmodernebb technológia, azaz az $5 \mathrm{G}$ fejlesztése terén lemaradt a versenytársakkal, úgy Kínával, mint sok tekintetben az Európai Unióval szemben is. Amerikai szempontból különösen kellemetlen

ZHENG-WU 2019. 
a kérdés, hiszen jelen esetben nem egy szövetséges állam viszi a prímet, hanem egy nagyhatalmi vetélytárs.

A The Chinese University of Hong Kong oktatói szerint az akadémiai kutatások és a szakértői előrejelzések egybehangzóan megerősítik, hogy a kínai-amerikai kereskedelmi háborúnak figyelemreméltó következményei lesznek mindkét állam esetében, azonban a gazdasági negatívumok az egész világgazdaságra kihatással bírnak majd. ${ }^{12}$ Vagyis elmondható, hogy a konfliktus hatásai nem fognak megállni a két nagyhatalom határainál, hanem világszintű kihatásai lesznek. Az Európai Unió meghatározó telekommunikációs vállalatainak - Vodafone, Deutsche Telekom - vezetői szerint a Huawei elleni fellépés mintegy két év hátrányt jelentene az európai 5G-hálózat kiépítésében. ${ }^{13}$ Márpedig Európa nagyon kiéhezett a sikerre, arra a gazdasági sikerre, amely az utóbbi évek gazdasági mutatói szerint igencsak elkerüli. A kínai-amerikai kereskedelmi háború pedig semmi jóval nem kecsegtet az európai államok gazdasági lehetőségeivel kapcsolatosan, sőt „mint amikor egy csillogó Mercedes beszorul két kamion közé, úgy téríti le pályájáról az európai gazdaságot az Egyesült Államok és Kína kereskedelmi konfliktusa". ${ }^{14}$ Az európai gazdaság ugyanis jelenleg rendkívüli mértékben kiszolgáltatott mind Kína, mind az Amerikai Egyesült Államok irányában. ${ }^{15}$ Ez pedig nem jelent mást, mint hogy a világvezető két állam kereskedelmi háborúja nemzetbiztonsági kérdésként jelentkezik az európai országok számára.

A csatározás ugyanis súlyos következményekkel járhat, hiszen „nem kétséges, hogy a legnagyobb fejlődő és a legnagyobb fejlett ország közötti kereskedelem háború hátrányosan érinti a globális gazdasági és kereskedelmi fejlődést, és rombolja a kereskedelmi kapcsolatokat". ${ }^{16}$ Egy olyan szituációban, amelyben a globalizáció hatására a nemzetek egymásrautaltsága sokkal erősebben érvényesül, mint bármikor korábban.

Minél tovább tart a szembenállás, annál jelentősebb, általános negatív következményekkel kell számolni, mivel „az USA és Kína között az elsőbbségért folyó harc hullámai - közvetve vagy közvetlenül - egyre több országot érnek el, növelve az általános bizonytalanság érzését, a cégek működési kockázatait, és ezzel a világgazdasági válság esélyeit". ${ }^{17}$ Ezekben az államokban pedig nagy valószínűséggel olyan társadalmi folyamatok indulhatnak meg, amelyek esetlegesen fegyveres konfliktusokhoz is vezethetnek.

A szembenállás kimenetele nehezen jósolható meg, mivel a Kínai Népköztársaság kapcsán megállapítható, hogy az mindinkább keményfejü globális szereplő, amely erőteljesen képviseli a nemzeti érdekeit. ${ }^{18}$ Mivel pedig Hszi Csin-ping kínai államfő „elérkezettnek látja az időt arra, hogy Kína jelentős, vezető szereplőként lépjen fel a világban, és ennek megfelelően alakítja az ország biztonságpolitikáját", ${ }^{19}$ ezért várható, hogy Peking mind kevesebb hajlandóságot fog mutatni arra, hogy meghátráljon az amerikaiakkal szemben.

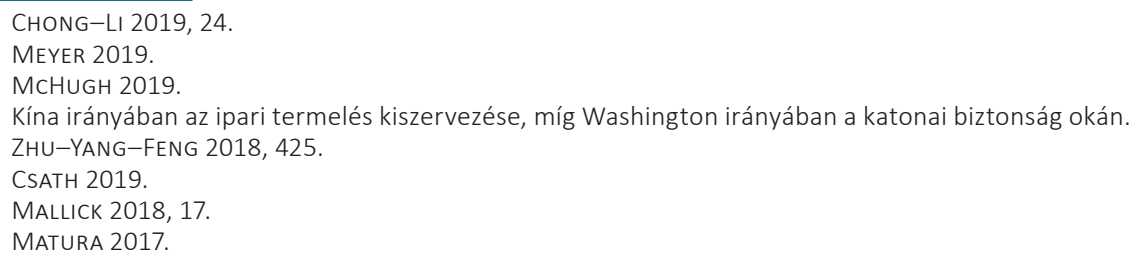


A Southeast Asia and Oceania for the International IMD Business School vezetője, Winter Nie szerint az Amerikai Egyesült Államok nem nyerhet meg egy kereskedelmi háborút Kínával szemben, mivel a világgazdaság egyéb szereplői (Európai Unió, DélKorea) örömmel veszik át a piacot és a termelési lehetőséget is az amerikaiaktól, ha azok kivonulnak Kínából. Ugyanakkor maguk a kínaiak is nyitottak arra, hogy ne amerikai, hanem máshonnan származó termékeket vásároljanak. Nie példaként hozza, hogy a kínai repülőgéppiacon ugyanolyan jól lehet Airbust eladni, mint Boeinget, ha az amerikaiak kivonulnak, de a gépjármúvek terén is a BMW vagy a Volkswagen bármikor ugyanolyan jól értékesíthető, mint a Ford. Azonban az amerikaiak esetében csak és kizárólag a piac- és befolyásvesztés jelenhet meg. ${ }^{20}$

A konfliktus tehát a nemzetközi paletta minden államára negatív hatásokkal jár, olyan hatásokkal, amelyeknek erős nemzetbiztonsági kihatásuk van.

\section{A magyar nemzetbiztonságra gyakorolt hatás}

Az elmúlt évtizedek során kiépült komplex és összefüggő globális viszonyrendszerben a ritkaföldfémek kitermelése és kereskedelme kapcsán kialakult feszült viszonyrendszer minden állam, így Magyarország életére is jelentős hatást gyakorol; egyaránt kiemelkedők a gazdasági, a politikai, valamint a nemzetbiztonsági vonatkozásai is. Magyarország esetében számos olyan nemzetbiztonsági attitűd jelentkezhet, amelyekre érdemes előzetesen is felkészülni, továbbá célszerűnek mutatkozhat a megfelelő válaszlépések mihamarabbi kidolgozása. Megállapítható, hogy az Amerikai Egyesült Államok és Kínai Népköztársaság kapcsolatrendszere egy fontos váltóponthoz érkezett, amelynél az egyetlen helyes út a mindkét fél számára előnyös kapcsolatok fenntartása, ugyanis az esetleges távolodás rendkívüli gazdasági recessziót eredményezhet mind a két oldalon. ${ }^{21}$ Ennek bekövetkezése pedig Magyarország számára kedvezőtlen pénzügyi, gazdasági és politikai hatásokkal járna.

Magyarország vonatkozásában a kínai-amerikai szembenállás elsősorban áttételes problémakörön keresztül jelentkezhet, a közvetlen fenyegetettség valószínűsége alacsonynak mondható. A jelenlegi gazdasági, politikai és biztonsági viszonyok mellett valószerűtlennek tűnik, hogy bármely, a konfliktusban szerepet vállaló állami vagy nem állami szereplő, akár az Amerikai Egyesült Államokkal, akár a Kínai Népköztársasággal fenntartott magyar kapcsolatok miatt lépéseket tenne hazánkkal szemben. ${ }^{22}$ Ugyanakkor a konfliktus közvetett hatásai több irányból is kiemelt biztonsági kockázatokat eredményezhetnek, amelyek akár egyfajta krízishelyzetben is manifesztálódhatnak. A magyar-kínai, illetve a magyar-amerikai kapcsolatok kiemelt stratégiai jelentőségéből adódóan azonban bármelyik reláció sérülése súlyos nemzetbiztonsági kockázatokat okoz.

NIE 2017.

MELTZER-ShenAI 2019, 22.

Érdemes azonban megjegyezni, hogy egyes vezető amerikai politikusok szerint Washingtonnak nem szabadna a jövőben megosztania titkosszolgálati információkat olyan államokkal, amelyek a Huawei technológiáját alkalmazzák. KHARPAL 2020. 
Az amerikai kapcsolatok kiegyensúlyozott keretek között tartása Magyarország elsődleges nemzetbiztonsági érdeke. Az Amerikai Egyesült Államok által vezetett Észak-atlanti Szerződés Szervezete (NATO) teremti ugyanis meg azt a biztonsági dimenziót, amely az ország külső fenyegetettségektől való védettségére lehetőséget biztosít, illetve amely lehetővé teszi egy esetleges hagyományos támadással szembeni hatékony fellépést. Vagyis elmondhatjuk, hogy Magyarország fizikaifenyegetésnélküliségének egyik fontos biztosítéka a Washingtonnal fenntartott jó kapcsolat, illetve hazánk NATO-tagsága.

A kínai relációt figyelembe véve, nem hagyható figyelmen kívül, hogy Magyarország régiós vezető szerepre törekszik a Pekinggel fenntartott kapcsolatok, illetve azok megvalósulásának koordinációja tekintetében. A magyar-kínai gazdasági kapcsolatok kiemelt fontossággal bírnak, mégpedig elsősorban Magyarország szempontjából. Nem szabad figyelmen kívül hagyni, hogy egyre több az olyan szakértő is, aki szerint mára éppen Kína érdeke a globális szabadkereskedelem megvalósulása, míg az Amerikai Egyesült Államok a nagyhatalmak által felügyelt, zárt régiók protekcionista kereskedelmi rendszerében látja a világgazdaság jövőjét. ${ }^{23}$ Ez pedig azt jelenti, hogy valószínűsíthetőleg Peking mindenképpen igyekszik majd fenntartani a Magyarországgal meglévő kölcsönösségi alapokon nyugvó jó kapcsolatait, illetve növelni az együttműködés színvonalát és volumenét. Mindazonáltal a két ország közötti kereskedelmi együttmúködés elsősorban magyar érdek.

A veszélyeztetettség megjelenése, illetve fokozódása a nemzetbiztonsági feladatkör több aspektusát is érintheti. Valószínúsíthető, hogy elsősorban a gazdaságbiztonság területén következhetnek be olyan negatív tendenciák, amelyek Magyarország nemzetbiztonságára veszélyt jelenthetnek. A kínai-amerikai szembenállás eredményezhet ugyanis egy olyan sajátos helyzetet, amelyben egyik vagy másik, a konfliktus által érintett félnek az érdekei a másik térségből való kiszorítására tett - akár közvetett, akár közvetlen - kísérletekben manifesztálódhat.

A korábbiakban felvázolt nemzetközi összefüggéseket figyelembe véve Magyarország elsődleges érdeke fenntartani a korábban kialakult jó kapcsolatot mind a két nagyhatalommal, illetve minimalizálni az azok között zajló konfliktus nemzetközi következményeiből adódó károk bekövetkezésének lehetőségét.

\section{Összegzés}

A kínai gazdasági potenciál, a folyamatosan növekvő vásárlóerő párosulva a ritkaföldfémek kereskedelmében betöltött kulcspozíció tényével egyértelmúvé teszi, hogy a Kínai Népköztársaság már megkerülhetetlen, világméretű hatalmi tényező. „Ma Kína a világ második legnagyobb gazdasága, ipari szuperhatalom, kereskedelmi szuperhatalom, második legnagyobb felhasználója a fogyasztási cikkeknek, ide érkezik a második legnagyobb külföldi tőkebeáramlás, a kínai devizatartalék a világ első helyezettje, a kínai nép gazdag. A kínai nép határozott lépéseket tett egy nagy úton!"24

SZÉNÁSI 2019, 11.

XI 2018. 
Mint új, felemelkedő nagyhatalom Kína jelentős kihívást jelent a jelenlegi nemzetközi keretek között meghatározó kulcsállamok, elsősorban az Amerikai Egyesült Államok, és részben a szövetségesei számára is.

A kínai-amerikai kereskedelmi konfliktussal kapcsolatosan megállapítható, hogy annak továbbvitele vagy kiszélesítése sem az Amerikai Egyesült Államoknak, sem a Kínai Népköztársaságnak nem érdeke, mivel annak következtében súlyos gazdasági hátrányok érhetik mind a két állam nemzetgazdaságát. „Kardcsörtetéssel és negatív hullámokkal megtelő világunkban tehát talán a legnagyobb garanciánk a békére az, hogy a nagyhatalmak nem ismernek újabb példákat a sikeres háborúra." ${ }^{25}$ A gazdasági szembenállás ilyen szinten való megvalósulása a globalizáció jelenlegi, hálózatosodást mutató kereteiben, a világ vitathatatlanul két legnagyobb gazdasági hatalma között, pontosan azt a példanélküliséget mutatja, amelyről a neves izraeli tudós, Yuval Noah Harari ír. A csatározás kimenetele nem lehet sikeres, nem lehet győztese egy ilyen háborúnak, a végelszámolásnál legfeljebb azt lehetne megállapítani, hogy az egyik résztvevő kevesebb veszteséget kellett, hogy elkönyveljen, mint a másik. Annak ellenére pedig, hogy Donald Trump szerint az Amerikai Egyesült Államok jobban viselné az adódó veszteségeket, egyáltalán nem biztos, hogy az események elfajulása esetén a befektetők, illetve az amerikai választók továbbra is osztanák a véleményét.

A két ország gazdasági életére gyakorolt negatív hatásokon túlmutatóan azonban megállapíthatók a globális kivetítődésekben rejlő veszélyek is, amelyek egyértelmű negatívumokat jelentenek a világgazdaság szempontjából. Vagyis kijelenthetjük, hogy a konfliktusban részt vevő két állam egész világot behálózó gazdasági jelenléte miatt egy kiéleződő vagy elhúzódó kereskedelmi csatározásnak gyakorlatilag minden egyes állam a kárvallottja lenne. A globalizáció folyamatainak eredményeként ugyanis nem vagy csak minimálisan találni olyan országot, amely gazdaságilag, politikailag, illetve biztonsági szempontok alapján ne lenne függő egyik, másik, vagy akár mind a két államtól. Ez azonban azt jelenti, hogy a globális sakktáblán jelenleg nem szerepel olyan figura, amelynek relatív érdeke füződne ahhoz, hogy a két nagyhatalom viszonya konfliktusos maradjon.

Számos nemzetközi elemző úgy véli, hogy a következő évtizedben a két nagy állam dominanciája miatt ismét a normál rendszer fog helyreállni. ${ }^{26}$ Azonban ez a fentebb leírtak és a bizakodás ellenére sem egyértelmü, ugyanis a történelmi események gyakran éppen a hasonló konfliktusok végletekig való kiéleződését, nem pedig az elcsitulását mutatják. Miközben jelentős számú szakértő éppen úgy vélekedik, hogy sem a Trump-adminisztráció, sem a kínai vezetők nem készültek még fel az érdemi tárgyalásokra, holott azokat jó kilátások mellett lehetne megtenni. ${ }^{27}$

Amennyiben mégis a válság elhúzódásával járó forgatókönyv valósulna meg, annak hatásai jelenleg beláthatatlannak bizonyulnának a globális és az egyes nemzetgazdaságok vonatkozásában is, és világszerte jelentős biztonsági kockázatokat eredményeznének.

HARARI 2018, 159.

LAU 2019.

Wu 2019. 
Magyarország esetében, bár elsősorban áttételes fenyegetettségek révén, mégis jelentős kockázatokkal kellene számolni politikai, nemzetgazdasági, biztonsági és nemzetbiztonsági területen is. Magyarország érintettsége valószínűsíthető, hogy elsősorban, mint az Európai Unió tagállamának, a közösségi tagságból fakadó kötelezettségei révén lenne eredeztethető. Vagyis Brüsszel Kínával kapcsolatos álláspontja alapvetően befolyásolhatja a magyar-kínai kapcsolatokat is. Egy a konfliktussal összefüggésben kialakuló egységes uniós álláspont ugyanakkor korántsem biztos, hogy Magyarország gazdasági és biztonsági érdekeit szolgálná. Levonható az a következtetés, hogy a magyar-kínai, illetve a magyar-amerikai kapcsolatok stratégiai jelentőségéből eredeztethetően Magyarország nemzetbiztonsági érdekei azt kívánják, hogy a Kínai Népköztársaság és az Amerikai Egyesült Államok között zajló kereskedelmi háború a legrövidebb időn belül véget érjen.

A világméretűvé dagadó államközi konfliktus megoldása csak a két ország vezetőinek higgadt, közös döntései által lehetséges. Hogy ezek mennyire fognak megtörténni, azt előrejelezni szinte lehetetlen, mindenesetre bizakodásra adhatnak okot a Kínai Népköztársaság vezetőjének Xi Jin-pingnek a szavai: „A Kína és az Egyesült Államok közti nagyhatalmi kapcsolati modell megújítására mindeddig nem volt példa, amelyet követhettünk volna. Kínának és az Egyesült Államoknak együttes erőfeszítéssel kell elősegítenie a két ország közti nagyhatalmi kapcsolat új modelljének kiépítését azáltal, hogy növeli a párbeszédek gyakoriságát, szorgalmazza a kölcsönös bizalmat, kibővíti az együttmúködést, és felügyeli a vitákat."28

\section{Felhasznált irodalom}

HARARI, Yuval Noah (2018): 21 lecke a 21. századra. Budapest, Animus Kiadó. KISSINGER, Henry (2014): Kínáról. Budapest, Antall József Tudásközpont.

SzÉNÁSI Endre (2019): USA-Kína kereskedelmi háború és új világrend kialakulása. DOI: https://doi.org/10.1109/MMUL.2019.2936930

TENG, Xiaoping (1994): Excerpts from Talks Given in Wuchang, Shenzhen, Zhuhai and Shanghai: January 18 - February 21, 1992. In Selected Works of Deng Xiaoping Volume 3. 1982-1992. Beijing, Foreign Languages Press.

XI, Jinping (2017): A nagyhatalmi kapcsolatok új modelljét kell kiépítenünk Kína és az Egyesült Államok között. In Xı Jinping: Kína kormányzásáról. Budapest, Antall József Tudásközpont.

ZHU, Zeyan - YANG, Yaotang - FENG Shuqi (2018): Trade War between China and US. Conference: 2018 International Conference on Advances in Social Sciences and Sustainable Development. DOI: https://doi.org/10.2991/asssd-18.2018.88 


\section{Internetes források}

CHONG, Terence Tai-leung - LI, Xiaoyang (2019): Understanding China-US Trade War: Causes, Economic Impact, and the Worst-Case Scenario. Hong Kong, Lau Chor Tak Institute of Global Economics and Finance - The Chinese University of Hong Kong. Elérhető: www.igef.cuhk.edu.hk/igef_media/working-paper/IGEF/igef\%20working\%20paper\%20no.\%2071\%20english\%20version.pdf (A letöltés dátuma: 2019. 08. 26.)

CSATH Magdolna (2019): Mi lehet az amerikai-kínai kereskedelmi háború hátterében? Világgazdaság. Elérhető: www.vg.hu/velemeny/mi-lehet-az-amerikai-kinai-kereskedelmi-haboru-hattereben-2-1701715/ (A letöltés dátuma: 2019. 08. 26.)

KHARPAL, Arjun (2020): Senator seeks ban on US sharing intelligence with countries using Huawei 5 G gear. Elérhető: www.cnbc.com/2020/01/09/us-lawmakerseeks-intelligence-sharing-ban-with-countries-using-huawei.html (A letöltés dátuma: 2020. 01. 14.)

LAU, Lawrence J. (2019): How China can shrug off the impact of the US trade war on its economy and improve the lives of its citizens. Elérhető: www.scmp.com/ comment/insight-opinion/article/3011282/how-china-can-shrug-impact-ustrade-war-its-economy-and (A letöltés dátuma: 2019. 08. 27.)

MALLICK, P. K. (2018): US-CHINA Trade War: Analyses of Deeper Nuances and Wider Implications. VIF Paper. Elérhető: www.vifindia.org/sites/default/files/US-CHINATrade-War.pdf (A letöltés dátuma: 2019. 08. 26.)

Mandiner (2019): Lemondott John Bolton amerikai nemzetbiztonsági tanácsadó. Elérhető: https://mandiner.hu/cikk/20190910_lemondott_john_bolton_amerikai_nemzetbiztonsagi_tanacsado (A letöltés dátuma: 2019. 09. 23.)

Matura Tamás (2017): A Kínai Kommunista Párt 19. kongresszusa és egy új korszak hajnala. Stratégiai Védelmi Kutatóközpont Elemzések, 29. sz. Elérhető: https://svkk. uni-nke.hu/document/svkk-uni-nke-hu-1506332684763/svkk_elemzesek_2017_29_a_kinai_kommunista_part_19_kongresszusa_es_egy_uj_korszak_hajnala _-matura-t_.original.pdf (A letöltés dátuma: 2019. 09. 03.)

MATURA Tamás (2019): Az amerikai-kínai kereskedelmi konfliktus és ami mögötte van. Elérhető: https://merce.hu/2019/06/09/az-amerikai-kinai-kereskedelmikonfliktus-es-ami-mogotte-van/?fbclid=IwAR0t3zKRRxSezE8U4jm5C-NqKjBPEY9670QN1RNItllowo4AVIDrMHcmahA (A letöltés dátuma: 2019. 08. 05.)

MCHUGH, David (2019): US-China trade war leaves Europe as collateral damage. Elérhető: www.apnews.com/430bfb5fc12b40758fb41a57e4c9495f (A letöltés dátuma: 2019. 08. 29.)

Meltzer, Joshua P. - ShenAI, Neena (2019): The US-China economic relationship. Global Economy And Development. AEl-Brookings Policy Paper. Elérhető: www. brookings.edu/wp-content/uploads/2019/02/us_china_economic_relationship. pdf (A letöltés dátuma: 2019. 08. 25.) 
MEYER, David (2019): The U.S. Is Losing Its Crusade Against Huawei. Elérhető: https:// fortune.com/2019/04/24/us-huawei-ban-uk/ (A letöltés dátuma: 2019. 08. 24.)

NIE, Winter (2017): The US would lose a trade war with China, 'bigly'. Elérhető: https:// thehill.com/blogs/pundits-blog/economy-budget/318135-the-us-would-lose-atrade-war-with-china-bigly (A letöltés dátuma: 2019. 08. 12.)

PolyÁk Eszter (2019): Kereskedelmi háború az USA és Kína között. Elérhető: www. geopolitika.hu/hu/2019/03/12/kereskedelmi-haboru-az-usa-es-kina-kozott/ (A letöltés dátuma: 2019. 08. 24.)

Wong, Dorcas - ChIPMAN KOTY, Alexander (2019): The US-China Trade War: A Timeline. Elérhető: www.china-briefing.com/news/the-us-china-trade-war-a-timeline/ (A letöltés dátuma: 2019. 09. 18.)

Wu, Wendy (2019): Beyond tariffs: China looks for new ways to hit back in US tech and trade war. Elérhető: www.scmp.com/news/china/diplomacy/article/3012740/ beyond-tariffs-china-looks-new-ways-hit-back-us-tech-and-trade (A letöltés dátuma: 2019. 08. 27.)

XI, Jinping (2018): Speech on 40th Anniversary of China's Reforms, Opening Up. Elérhető: www.transcend.org/tms/2018/12/xi-jinpings-speech-on-40th-anniversary-ofchinas-reforms-opening-up-full-text/ (A letöltés dátuma: 2019. 08. 29.)

ZHENG, Sarah - WU, Wendy (2019): Beijing to blacklist 'unreliable' foreign entities that 'hurt interests of Chinese firms'. Elérhető: www.scmp.com/news/china/diplomacy/article/3012675/beijing-blacklist-unreliable-foreign-entities-hurt-interests (A letöltés dátuma: 2019. 08. 29.) 